\title{
魚眼レンズ付デジタルカメラによる全天空分光放射輝度分布の測定法 MEASUREMENT OF THE ALL SKY SPECTRAL RADIANCE DISTRIBUTION USING A DIGITAL CAMERA WITH A FISHEYE LENS
}

\author{
八塚秀樹*, 上谷芳昭** \\ Hideki YATSUZUKA and Yoshiaki UETANI
}

\begin{abstract}
We developed a method of measuring the spectral radiance of all sky elements using a general purpose digital camera and a circular fisheye lens. The accuracy of the fisheye camera is adequate for practical daylight design. The instrument is portable for field measurements. The digital camera with the fisheye lens is colorimetrically calibrated to obtain the calibration functions which transfer the video signal values RGB on a digital color image into the absolute values of CIE 1931 tristimulus values XYZ pixel by pixel. The calibrated fisheye digital camera measures the all sky distribution of the XYZ tristimulus values. The XYZ tristimulus values are transferred into the all sky spectral radiance distribution in two ways: (1) by using the CIE daylight illuminant and (2) by using the eigenvectors obtained by principal component analysis of measured spectral radiances of the sky elements by a spectroradiometer. The accuracy of the all sky spectral radiance distribution is validated by comparison with the spectral radiance measured by the spectroradiometer.
\end{abstract}

\section{Keywords : Daylight source, Spectral Radiance, Fisheye lens, Video Colorimetry, XYZ Tristimulus Values, CIE Daylight Illuminant 昼光光源，分光放射輝度，魚眼レンズ，ビデオ測色法，XYZ 三刺激值，CIE 昼光}

1. はじめに

近年、JIS の室内作業場の照明基準 1)に演色性が追加された。一 般に人工光源の演色性のみが考慮されることが多いが、近年は省工 ネと快適性の観点から昼光を導入する建築空間が増えているので、 昼光と人工光を含めた総合的な演色性を考えるべきである。また、 サーカディアンリズムが特定の波長に影響されることが指摘されて (いる 2) 3)。光源の演色性やサーカディアンリズムへの影響などを考 慮する場合、昼光および人工光の分光分布を用いて昼光照明設計を 行う必要がある。

天空の分光分布として色彩の分野で標準化された CIE 昼光 ${ }^{4) か ゙ あ ~}$ るが、CIE 昼光は受光角 $6^{\circ} \sim 180^{\circ}$ の分光放射計による、直射日光を 含む天空光の測定に基づいている。したがって、太陽およびその周 辺以外の天空要素の様々な高度や方位角における分光分布を $\mathrm{CIE}$ 昼光により合成することが可能かどうかは明らかではない。

空の方位の違いや天空光の天気・季節・時間の変化などを考慮し た昼光照明設計を行うためには、分光放射輝度の全天空分布 (以下、 全天空分光放射輝度分布と呼ぶ）のデータベースが必要である。全 天空分光放射輝度分布は、大気の状態に依存するので地域によって 異なる。今後様々な地域で全天空分光放射輝度分布のデータベース を整備するためには、可搬型装置による測定法の開発が必要である。
分光放射計を搭載したスカイスキャナで天空を走査し、全天空分 光放射輝度分布を測定する研究 5)が行われているが、装置が大掛か りで容易に移動できない。また、天空相関色温度分布の測定に関す る研究 6) 7)が行われているが、分光分布を測定するまでには至って いない。さらに、天空輝度分布の推定式から相関色温度を介して CIE 昼光で天空要素の相対分光分布を推定する研究 8)も行われているが、 雲塊の分布状態を反映するのは困難である。

魚眼レンズとデジタルカメラを用いて全天空輝度分布の測定を行 う研究 9) 1011) は分光分布を測定することを目的としていない。魚眼 レンズと光学フィルタを取り付けたデジタルカメラを暗室で較正し、 全天空分光放射輝度分布を測定する研究 ${ }^{12)}$ 、魚眼レンズを取り付け た画像処理用の高精度デジタルカメラをサントラッカーによる直射 日光遮蔽装置の付いた回転台に乗せ、全天空分光放射輝度分布を測 定する研究 13) 14)がある。しかし、これらはデジタルカメラの信号值 から直接的に分光分布を導出する較正を行うため、カメラの特性に 大きく依存しており、カメラを変えればその都度手間のかかる較正 が必要となる。また装置も大掛かりで容易に移動できない。

本研究の目的は、汎用の魚眼レンズ付デジタルカメラを用いて、 昼光・人工光併用照明設計を行うために実用上十分な精度があり可 搬性のある全天空分光放射輝度分布の測定法を開発することである。
本論文は既報18)19）に加筆・修正を加えたものである。

* 京都大学大学院工学研究科建築学専攻 修士課程

** 京都大学大学院工学研究科建築学専攻 准教授.工博
Graduate Student, Dept. of Architecture, Graduate School of Eng., Kyoto University Assoc. Prof., Dept. of Architecture, Graduate School of Eng., Kyoto University, Dr. Eng. 
まず、ビデオ測色法 ${ }^{15)}$ により魚眼レンズ付デジタルカメラを用い てXYZ 三刺激值の絶対值の全天空分布 (以下、全天空 XYZ 三刺激 值分布と呼ぶ）を測定する。暗室にて比較的簡易な色彩較正を行え ば、撮像素子の分光感度特性が未知の汎用デジタルカメラを用いて 全天空 XYZ 三刺激值分布を測定することができる。

次に、 2 通りの方法で全天空 XYZ 三刺激值分布から全天空分光放 射輝度分布を導出する。(1) CIE 昼光によって全天空 XYZ 三刺激值 分布から全天空相関色温度分布を求め、全天空分光放射輝度分布を 導く。(2) 様々な天空の分光放射輝度を分光色彩計で測定して主成 分分析を行うことによって得られる固有べクトルを用いて、全天空 $\mathrm{XYZ}$ 三刺激值分布から全天空分光放射輝度分布を求める。

\section{2. ビデオ測色法による全天空 $X Y Z$ 三刺激値分布の測定}

ビデオ測色法 ${ }^{15)}$ とは、アナログ・デジタルを問わずカラービデオ カメラを色彩計で較正し、CIE 表色系三刺激值 XYZ の絶対值を計 測する方法である。

\section{1 色彩較正の基本式}

まず、魚眼レンズ付デジタルカメラの色彩較正を行い、デジタル カメラの RGB 信号值から XYZ 三刺激值の絶対值を求めるための色 彩較正関数を求める。暗室において光源によって照射された色票を 魚眼レンズ付デジタルカメラで撮影すると同時に、色彩計による $\mathrm{XYZ}$ 三刺激值の絶対值の測定を行う。

デジタルカメラの色域は AdobeRGB に設定し、その仕様 16)に従 って色彩較正関数を以下のように導く。分解能 $Q$ [bit]のデジタルカ メラの RGB 信号值 $\left(R^{\prime}{ }_{v Q} G^{\prime}{ }_{v Q}, B^{\prime}{ }^{\prime}{ }^{\prime}\right)$ は式(1)によって正規化 RGB 成分值 $\left(R^{\prime}, G_{v}{ }_{v}, B^{\prime}{ }_{v}\right)$ とする。正規化 RGB 成分值 $\left(R^{\prime}{ }_{v}, G_{v}{ }_{v}, B^{\prime}{ }_{v}\right)$ は、 式(2)により逆ガンマ補正をし、正規化 RGB 三刺激值 $\left(R_{v}, G_{v}, B_{v}\right)$ に変換する。

$\left\{\begin{array}{l}R_{v}^{\prime}=R^{\prime}{ }_{v Q} /\left(2^{Q}-1\right) \\ G_{v}^{\prime}=G_{v Q}^{\prime} /\left(2^{Q}-1\right) \\ B_{v}^{\prime}=B^{\prime}{ }_{v Q} /\left(2^{Q}-1\right)\end{array}\right.$
$\left\{\begin{array}{l}R_{v}=R^{\prime}{ }_{v} 2.19921875 \\ G_{v}=G^{\prime}{ }_{v} 2.19921875 \\ B_{v}=B^{\prime}{ }_{v}{ }^{2.19921875}\end{array}\right.$

一方、色彩計による測色值 $\left(X_{s}, Y_{s}, Z_{s}\right)$ は式(3)によって RGB 三刺 激值 $\left(R_{s}, G_{s}, B_{s}\right)$ に変換する。 $\mathrm{RGB}$ 三刺激值 $\left(R_{s}, G_{s}, B_{s}\right)$ は、式(4) により、色彩較正の基準值である $\mathrm{RGB}$ 成分值 $\left(R{ }_{s}{ }_{s}, G_{s}{ }_{s}, B_{s}{ }_{s}\right)$ に変換 する。

$$
\begin{aligned}
& {\left[\begin{array}{l}
R_{s} \\
G_{s} \\
B_{s}
\end{array}\right]=\left[\begin{array}{ccc}
2.04159 & -0.56501 & -0.34473 \\
-0.96924 & 1.87597 & 0.04156 \\
0.01344 & -0.11836 & 1.01517
\end{array}\right]\left[\begin{array}{c}
X_{s} \\
Y_{s} \\
Z_{s}
\end{array}\right]} \\
& \left\{\begin{array}{l}
R_{s}^{\prime}=R_{s}{ }^{1 / 2.19921875} \\
G_{S}^{\prime}=G_{s}{ }^{1 / 2.19921875} \\
B^{\prime}{ }_{s}=B_{s}{ }^{1 / 2.19921875}
\end{array}\right.
\end{aligned}
$$

正規化 RGB 三刺激值 $\left(R_{v}, G_{v}, B_{v}\right)$ および RGB 成分値 $\left(R{ }_{s}{ }_{s}, G_{s}{ }_{s}, B_{s}{ }_{s}\right)$ について、最小二乗法による回帰分析を行い、その回帰式である色 彩較正関数 $\left(f_{r}, f_{g}, f_{b}\right)$ を求める。色彩較正関数 $\left(f_{r}, f_{g}, f_{b}\right)$ が得られ ると、正規化 RGB 三刺激值 $\left(R_{v}, G_{v}, B_{v}\right)$ から式(5)によって RGB 成 分值 $\left(R_{v s}^{\prime}, G_{v s}^{\prime}, B_{v s}^{\prime}\right)$ を求めることができる。 RGB 成分值 $\left(R_{v s}^{\prime}, G_{v s}^{\prime}\right.$, $\left.B^{\prime}{ }_{v s}\right)$ は式(6)によって逆ガンマ補正をし、RGB 三刺激值 $\left(R_{v s}, G_{v s}, B_{v s}\right)$
に変換する。 $\mathrm{RGB}$ 三刺激值 $\left(R_{v s}, G_{v s}, B_{v s}\right)$ を式(7)によって XYZ 三 刺激值に変換し、ビデオ測色法による XYZ 三刺激值（以下、ビデ 才測色值と呼ぶ）（ $\left.X_{v s,}, Y_{v s}, Z_{v s}\right)$ を得る。

$$
\begin{aligned}
& \left\{\begin{array}{l}
R_{v s}^{\prime}=f_{r}\left(R_{v}\right) \\
G_{v s}^{\prime}=f_{g}\left(G_{v}\right) \\
B_{v s}^{\prime}=f_{b}\left(B_{v}\right)
\end{array}\right. \\
& \left\{\begin{array}{l}
R_{v s}=R_{v s}^{\prime} 2.19921875 \\
G_{v s}=G_{v s}^{\prime} 2.19921875 \\
B_{v s}=B_{v s}^{\prime}
\end{array} 2.19921875\right. \\
& {\left[\begin{array}{l}
X_{v s} \\
Y_{v s} \\
Z_{v s}
\end{array}\right]=\left[\begin{array}{lll}
0.57667 & 0.18556 & 0.18823 \\
0.29734 & 0.62736 & 0.07529 \\
0.02703 & 0.07069 & 0.99134
\end{array}\right]\left[\begin{array}{l}
R_{v s} \\
G_{v s} \\
B_{v s}
\end{array}\right]}
\end{aligned}
$$

\section{2 色彩較正の方法}

まず、表 1 に示すように設定したデジタルカメラ (Nikon D5000) に等立体角射影方式の円周魚眼レンズ（SIGMA $4.5 \mathrm{~mm} \mathrm{F2.8} \mathrm{EX}$ DC Circular Fisheye HSM）を取り付け、暗室にてキセノンランプ

(USHIO Optical Modulex SX-UI501XQ) によって照射された無 彩色の色票（MacBeth ColorChecker No.19〜No.24）を撮影する。 その際、色票とキセノンランプの ND フィルタ（透過率 0.2、0.05、 0.01）の組从合わせにより色票表面の輝度を変化させる。撮影と同 時に、分光色彩計 (Photo Research PR-650 SpectraScan Colorimeter）によるXYZ 三刺激值の絶対值の測定を行う。

次に、RAW 画像を16bit Tiff 画像に変換して読み取った RGB 信 号值 $\left(R^{\prime}{ }^{\prime} 16, G^{\prime}{ }_{v 16}, B^{\prime}{ }_{v 16}\right)$ と色彩計測色值 $\left(X_{s}, Y_{s}, Z_{s}\right)$ から 2.1 の方法 で色彩較正関数を求める。

\section{3 色彩較正の結果}

図 1 にシャッタースピード $1 / 100$ 秒（以下 SS: 1/100）の RGB 成 分值の正規化 RGB 三刺激值に対する回帰曲線を、表 2 に色彩較正 関数を示す。なお、回帰曲線は複数の多項式による回帰分析を試み、 決定係数が最も高いものを選んだ。

さらに、色彩較正関数を使って色票のビデオ測色值 $\left(X_{v s}, Y_{v s}, Z_{v s}\right)$ を算出し、色彩計測色值 $\left(X_{s}, Y_{s}, Z_{s}\right)$ と比較した。図 2 に SS: $1 / 100$ の XYZ と相関色温度の散布図を、表 3 に精度の統計指標として MBE, RMSE, \%MBE, \%RMSE を示す。統計指標はいずれも小さく 精度は良好であった。色彩較正における色票の XYZ 三刺激值の絶 対值の範囲を表 4 に示す。得られた色彩較正関数により、この範囲 の XYZ 三刺激值が測色可能である。

\section{4 魚眼レンズ付デジタルカメラの入射角特性}

レンズの光軸に対する光の入射角が $0^{\circ}$ のときの $\mathrm{RGB}$ 信号值と 任意の入射角における RGB 信号值の比を魚眼レンズ付デジタルカ メラの入射角特性と呼ぶ。魚眼レンズ付デジタルカメラを水平方向 に回転させ、入射角を $0^{\circ}$ から $10^{\circ}$ 毎に変えて色票を撮影した。図 3 にその結果を示す。入射角の違いによる RGB 信号值の変動はわ ずかであったが、回帰曲線を作成し、補正を行った。

表 1 デジタルカメラの設定

\begin{tabular}{|c|c||c|c|}
\hline 画像モード & 12bitRAW+FINE & 色域 & AdobeRGB \\
\hline ホワイドランス & 曇天 & 絞り值 & F22 \\
\hline ISO感度 & 200 & シャッタースピード & $1 / 40 、 1 / 100 、 1 / 250$ \\
\hline
\end{tabular}




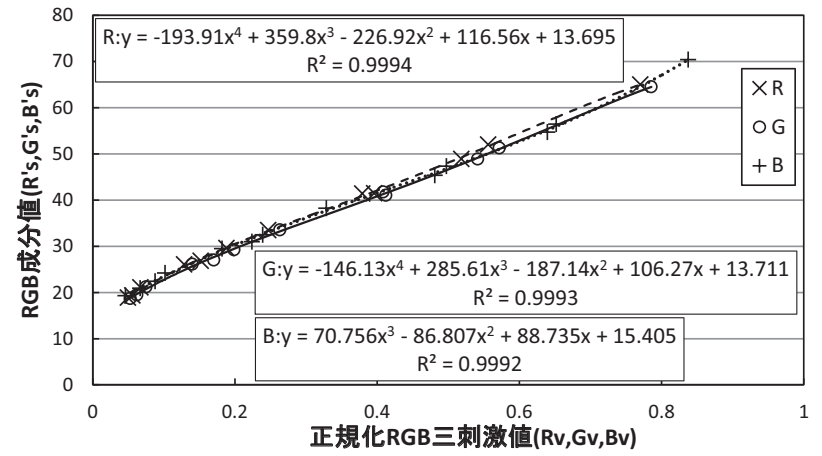

図 1 RGB 成分值の回帰曲線（SS: 1/100）

表 2 色彩較正関数

\begin{tabular}{|c|c|c|c|}
\hline SS & 定義域 & 色彩較正関数 & $\begin{array}{c}\text { 決定係数 } \\
\mathrm{R}^{2}\end{array}$ \\
\hline \multirow{3}{*}{$1 / 40$} & $0.0207<\mathrm{R}_{v}<0.7695$ & $R_{s}^{\prime}=-256.82 R_{v}{ }^{4}+435.45 R_{v}{ }^{3}-251.67 R_{v}{ }^{2}+96.696 R_{v}+7.8456$ & 0.9992 \\
\hline & $0.0223<\mathrm{G}_{\mathrm{v}}<0.7828$ & $\mathrm{G}_{\mathrm{s}}=-182.42 \mathrm{G}_{\mathrm{v}}{ }^{4}+332.10 \mathrm{G}_{\mathrm{v}}{ }^{3}-205.79 \mathrm{G}_{\mathrm{v}}{ }^{2}+87.973 \mathrm{G}_{\mathrm{v}}+7.8635$ & 0.9989 \\
\hline & $0.0312<\mathrm{B}_{\mathrm{v}}<0.6942$ & $\mathrm{~B}_{\mathrm{s}}^{\prime}=25.257 \mathrm{~B}_{\mathrm{v}}{ }^{4}+27.939 \mathrm{~B}_{\mathrm{v}}{ }^{3}-66.779 \mathrm{~B}_{\mathrm{v}}{ }^{2}+66.117 \mathrm{~B}_{\mathrm{v}}+9.2676$ & 0.9983 \\
\hline \multirow{3}{*}{$1 / 100$} & $0.0503<\mathrm{R}_{\mathrm{v}}<0.7704$ & $R_{s}^{\prime}=-193.91 R_{v}{ }^{4}+359.80 R_{v}{ }^{3}-226.92 R_{v}{ }^{2}+116.56 R_{v}+13.695$ & 0.9994 \\
\hline & $0.053<G_{\mathrm{v}}<0.7854$ & $\mathrm{G}_{\mathrm{s}}^{\prime}=-146.13 \mathrm{G}_{\mathrm{v}}{ }^{4}+285.61 \mathrm{G}_{\mathrm{v}}{ }^{3}-187.14 \mathrm{G}_{\mathrm{v}}{ }^{2}+106.27 \mathrm{G}_{\mathrm{v}}+13.711$ & 0.9993 \\
\hline & $0.0465<\mathrm{B}_{v}<0.8377$ & $\mathrm{~B}_{\mathrm{s}}^{\prime}=70.756 \mathrm{~B}_{\mathrm{v}}{ }^{3}-86.807 \mathrm{~B}_{\mathrm{v}}{ }^{2}+88.735 \mathrm{~B}_{\mathrm{v}}+15.405$ & 0.9992 \\
\hline \multirow{3}{*}{$1 / 250$} & $0.0345<\mathrm{R}_{v}<0.5784$ & $R_{\mathrm{s}}^{\prime}=123.92 \mathrm{R}_{\mathrm{v}}{ }^{3}-162.96 \mathrm{R}_{\mathrm{v}}{ }^{2}+154.78 \mathrm{R}_{\mathrm{v}}+21.119$ & 0.9991 \\
\hline & $0.0372<G_{v}<0.5902$ & $\mathrm{G}_{\mathrm{s}}^{\prime}=106.95 \mathrm{G}_{\mathrm{v}}{ }^{3}-141.65 \mathrm{G}_{\mathrm{v}}{ }^{2}+145.11 \mathrm{G}_{\mathrm{v}}+20.910$ & 0.9992 \\
\hline & $0.0494<\mathrm{B}_{\mathrm{v}}<0.6643$ & $\mathrm{~B}_{\mathrm{s}}^{\prime}=64.986 \mathrm{~B}_{\mathrm{v}}{ }^{3}-99.739 \mathrm{~B}_{\mathrm{v}}{ }^{2}+132.05 \mathrm{~B}_{\mathrm{v}}+23.063$ & 0.9991 \\
\hline
\end{tabular}
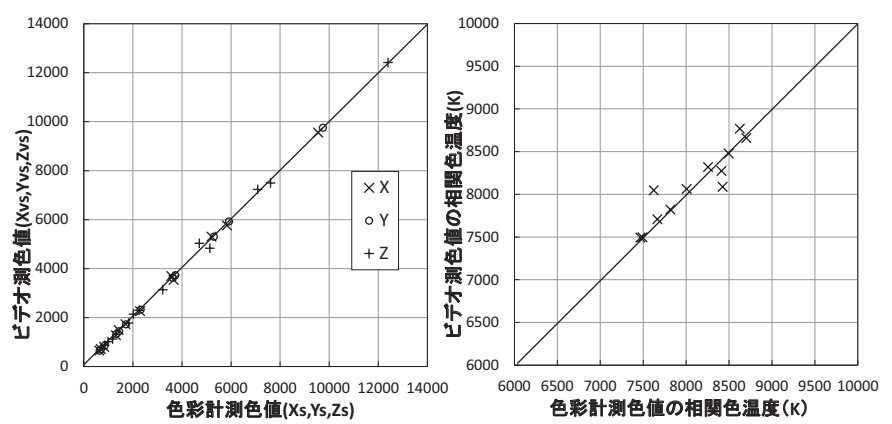

図 $2 \quad \mathrm{XYZ}$ 三刺激值と相関色温度の散布図（SS: 1/100）

表 $3 \mathrm{XYZ}$ 三刺激値と相関色温度の精度

\begin{tabular}{|c|c|c|c|c|c|c|c|c|c|c|c|c|}
\hline シャツタタースピード & \multicolumn{4}{|c|}{$1 / 40$} & \multicolumn{4}{|c|}{$1 / 100$} & \multicolumn{4}{|c|}{$1 / 250$} \\
\hline 三刺激值 & $\mathrm{x}$ & $\bar{Y}$ & $Z$ & $T c p$ & $x$ & $\bar{Y}$ & Z & Tсp & $x$ & $\mathrm{Y}$ & Z & Tcp \\
\hline MBE & 1.2 & 1.1 & -0.8 & -14 & \begin{tabular}{|l|}
-0.5 \\
\end{tabular} & 0.1 & -0.8 & 16 & -0.6 & 1.1 & 1.1 & -12 \\
\hline RMSE & 27.8 & 29.6 & 40.2 & 99 & 66.4 & 60.3 & 147.3 & 169 & 98.2 & 92.8 & 187.9 & 219 \\
\hline \%MBE & $\begin{array}{l}0.1 \\
\end{array}$ & $\begin{array}{ll}0.1 \\
\end{array}$ & -0.1 & -0.2 & \begin{tabular}{l|}
0.0 \\
\end{tabular} & $\begin{array}{l}0.0 \\
\end{array}$ & 0.0 & \begin{tabular}{l|}
0.2 \\
\end{tabular} & 0.0 & \begin{tabular}{|c|}
0.0 \\
\end{tabular} & 0.0 & -0.2 \\
\hline SMS & 3.0 & 3.2 & & & & & 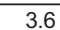 & & 2.0 & 4 & 2.9 & \\
\hline
\end{tabular}

表 4 色彩較正における色票の XYZ 三刺激值の絶対値の範囲

\begin{tabular}{|c|c|c|c|}
\hline シャッタースピード & $X$ & $\mathrm{Y}\left[\mathrm{cd} / \mathrm{m}^{2}\right]$ & $\mathrm{Z}$ \\
\hline $1 / 40$ & $148 \sim 2290$ & $149 \sim 2320$ & $212 \sim 3220$ \\
\hline $1 / 100$ & $636 \sim 9550$ & $643 \sim 9750$ & $854 \sim 12400$ \\
\hline $1 / 250$ & $1310 \sim 15000$ & $1330 \sim 15300$ & $1820 \sim 19200$ \\
\hline
\end{tabular}

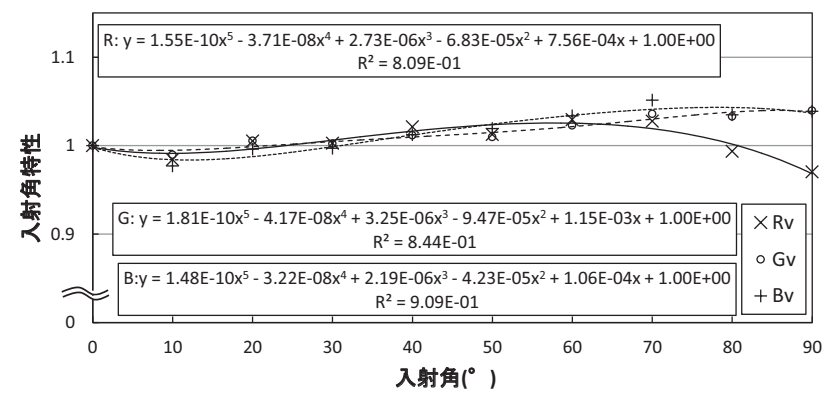

図 3 魚眼レンズ付デジタルカメラの入射角特性（SS:1/100）

\section{5 全天空 $X Y Z$ 三刺激值分布の測定法}

色彩較正した魚眼レンズ付デジタルカメラで全天空画像の撮影を 行う注1)。得られた画像から、画像処理ソフトを用いて RGB 信号值 を読み取り、色彩較正関数を用いてビデオ測色值に変換する。

検証のために、撮影と同時に表 5 に示す高度・方位角に全開口角 $1^{\circ}$ の分光色彩計（PR-650）を向け色彩計測色值および 3.3 で述べ る主成分分析で用いる分光放射輝度を測定する。雲の移動など、天 空条件の変化の影響を考慮し分光色彩計の高度・方位角を 1 2 回 変える毎に画像を撮影する。

\section{6 全天空 $X Y Z$ 三刺激值分布の測定結果}

測定は京都大学桂キャンパスにて行い、2012 年 2 月 9 日 9:48 11:14 (快晴) に 177 枚（各 SS: 59 枚）、同日 14:00 14:37 (晴) に 195 枚 (各 SS: 65 枚)、計 372 枚 (各 SS: 124 枚) の画像を得た。 図 4 に当日の昼光照度の変化を示す。表 5 に示寸高度・方位角の全 開口角 $1^{\circ}$ の天空要素に対応する画素（図 5）のビデオ測色值を求 め、対応する色彩計測色值と比較した。図 6 に XYZ 三刺激值の絶 対值の散布図と相関色温度の散布図を、表 6 に精度の統計指標の值 を示す。なお、SS: $1 / 40$ は画像が白とびしたものが多く、有効デー 夕数が少なかったため省略する。表 6 において、\%RMSE の值は XYZ 三刺激值で $20 \%$ 前後と精度はおおむね良好であった。相関色温 度は $30 \%$ 程度となったが、量天時のみの場合では\%RMSE の值は 10\%前後と精度は良好であった。図 6(a)において、ビデオ測色值と 色彩計測色值はおおむね致しているが、両者が大きく異なるもの もある。これは、全開口角 $1^{\circ}$ の分光色彩計で雲と青空の境目など を測定する際、わずかな高度・方位のずれによって測定值が大きく 変わってしまうためであると考えられる。図 6(b)において、ビデオ 測色值の相関色温度と色彩計測色值の相関色温度は $10000 \mathrm{~K}$ 以下で はおおむね一致しているが、10000K 以上では一致しないものが多 い。また、表 6 では、相関色温度の高い快晴時の\%RMSE が曇天時 より大きい。これらは、色彩較正の際に無彩色の色票のみを使用し たため、色彩較正関数の相関色温度に関する適用範囲が狭かったた めと考えられる。有彩色の色票を用いて色彩較正を行えば、相関色 温度の範囲が拡大し、相関色温度の高い領域での精度が向上する可 能性がある。

表 5 分光色彩計により測色する高度・方位角

\begin{tabular}{|c|c|c|c|c|c|}
\hline 高度 & 方位角 & データ数 & |高度 & 方位角 & データ数 \\
\hline $90^{\circ}$ & - & 1 & $40^{\circ}$ & $0^{\circ}, 20^{\circ}, \cdots, 340^{\circ}$ & 18 \\
\hline $80^{\circ}$ & $0^{\circ}, 60^{\circ}, \cdots, 300^{\circ}$ & $\underline{6}$ & $30^{\circ}$ & $0^{\circ}, 20^{\circ}$ & 18 \\
\hline $70^{\circ}$ & $0^{\circ}, 30^{\circ}, \cdots, 330^{\circ}$ & 12 & $20^{\circ}$ & $0^{\circ}, 20^{\circ}, \cdots, 340^{\circ}$ & 18 \\
\hline $60^{\circ}$ & $0^{\circ}, 20^{\circ}, \cdots, 340^{\circ}$ & 18 & $10^{\circ}$ & $0^{\circ}, 20^{\circ}$ & 18 \\
\hline $50^{\circ}$ & $0^{\circ}, 20^{\circ}, \cdots, 340^{\circ}$ & 18 & & 計 & 127 \\
\hline
\end{tabular}

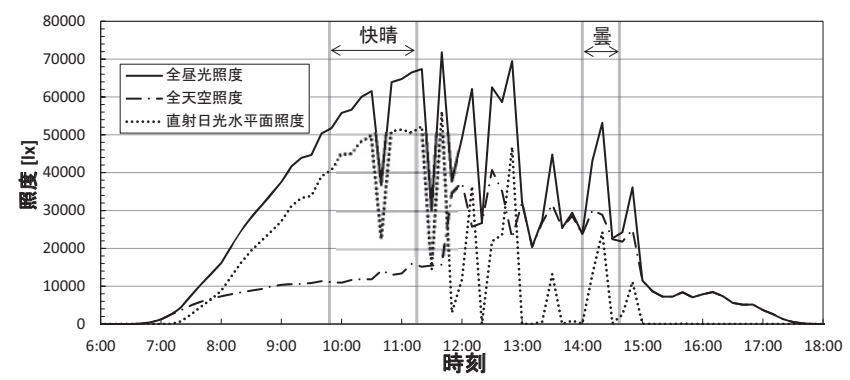

図 42012 年 2 月 9 日の昼光照度の変化と測定時の天気 


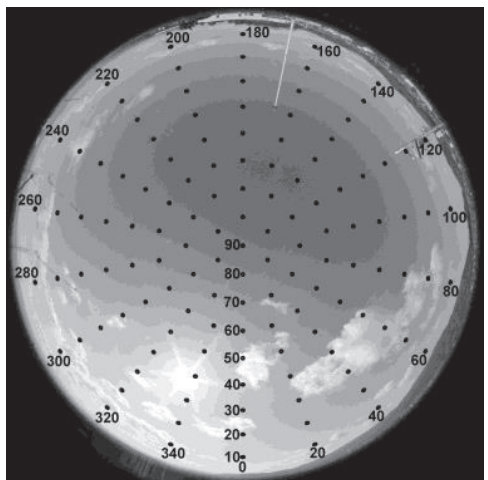

図 5 ビデオ測色值を求めた画像上の天空要素

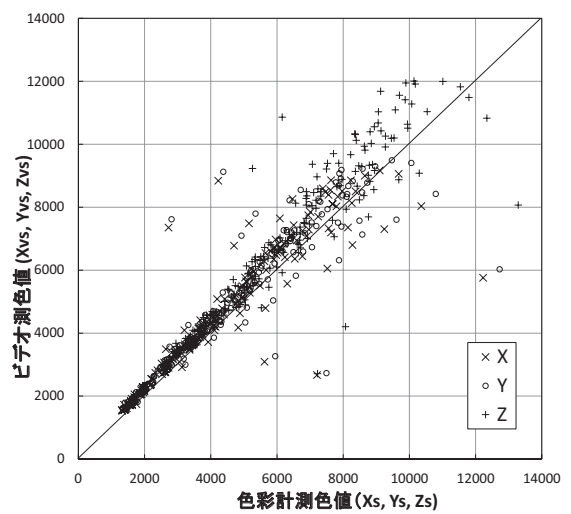
(a)XYZ 三刺激值の絶対伹

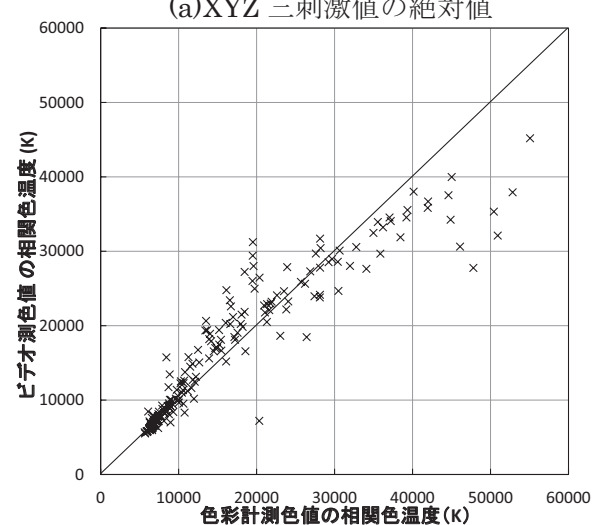

(b)相関色温度

図 6 ビデオ測色值と色彩計測色值の散布図 (SS: 1/100)

表 6 ビデオ測色值の精度

\begin{tabular}{|c|c|c|c|c|c|c|c|c|c|c|c|c|}
\hline \multirow[b]{2}{*}{ 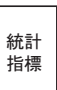 } & \multicolumn{6}{|c|}{ シャ゙ッタースピード1/100秒(n=192) } & \multicolumn{6}{|c|}{ シャツタースピード1/250秒 $(\mathrm{n}=221)$} \\
\hline & $\mathrm{x}$ & Y & z & Tcp & \begin{tabular}{|c|c|} 
Top \\
快晴時
\end{tabular} & 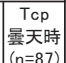 & $\mathrm{x}$ & Y & z & Top & 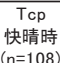 & 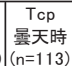 \\
\hline & 72. & 276.2 & & & -294 & 257 & & & & & 302 & \\
\hline & 0.9 & 91.0 & 0.4 & & 0101 & 1028 & 183 & 35.2 & 1135.8 & 458 & 302 & \\
\hline$B E$ & 6.4 & 6.2 & 9.3 & -0.3 & -1.2 & 3.2 & 6.6 & 6.7 & 6.8 & 1.1 & 1.5 & \\
\hline ASE & 22. & $22.4 \mid$ & 18 & 261 & 24.4 & 12.8 & 22. & 22.3 & 152 & $31.9 \mid$ & 30.8 & \\
\hline
\end{tabular}

\section{3. 全天空分光放射輝度分布の導出}

\section{$3.1 \mathrm{CIE}$ 昼光による方法}

2.で得られた各天空要素の XYZ 三刺激值から相関色温度を求め

て、CIE 昼光の相対分光分布 $S(\lambda)$ を算出寸る。

次に、相対分光分布 $S(\lambda)$ を分光放射輝度 $L(\lambda)\left[\mathrm{W} /\left(\mathrm{m}^{2} \cdot \mathrm{sr} \cdot \mathrm{nm}\right)\right]$ に変換する係数 $r$ を求める。 $L(\lambda)$ は $S(\lambda)$ と係数 $r$ を用いて式(8)のよ うに表せる。

$$
L(\lambda)=r S(\lambda)
$$

式(8)に最大視感度 $\mathrm{K}=6831 \mathrm{~m} / \mathrm{W}$ と $2^{\circ}$ 視野の等色関数 $\bar{y}(\lambda)$ をかけ、波 長 $\lambda$ で積分すると

$$
\mathrm{K} \int_{380}^{780} L(\lambda) \bar{y}(\lambda) d \lambda=r \mathrm{~K} \int_{380}^{780} S(\lambda) \bar{y}(\lambda) d \lambda
$$

となる。ここで、三刺激值 $Y$ の定義式より

$$
Y=\mathrm{K} \int_{380}^{780} L(\lambda) \bar{y}(\lambda) d \lambda
$$

であるため、式(9)より $r$ は次のように求められる。

$$
r=Y /\left(\mathrm{K} \int_{380}^{780} S(\lambda) \bar{y}(\lambda) d \lambda\right)
$$

得られた $r$ から式(8)を用いて分光放射輝度 $L(\lambda)$ を求める。

\section{2 主成分分析による方法}

昼光の分光分布に対して主成分分析を行う過去の研究としては、 相対分光分布に関寸る Judd らの研究 17)があるが、本研究の目的は、 天空要素毎の分光放射輝度を絶対值で求めることであるため、各值 を絶対值のまま扱う。まず、分光色彩計を用いて天空を測定し、 $N$ 組の分光放射輝度の測定データを用意する。これを式(12)のように $N$ 行 $m$ 列の行列 $\mathbf{L}$ で表す。ただし、 $\lambda_{1}, \lambda_{2}, \ldots, \lambda_{m}$ は波長である。

$$
\mathbf{L}=\left(\begin{array}{cccc}
L_{1}\left(\lambda_{1}\right) & L_{1}\left(\lambda_{2}\right) & \cdots & L_{1}\left(\lambda_{m}\right) \\
L_{2}\left(\lambda_{1}\right) & L_{2}\left(\lambda_{2}\right) & \cdots & L_{2}\left(\lambda_{m}\right) \\
\vdots & \vdots & \ddots & \vdots \\
L_{N}\left(\lambda_{1}\right) & L_{N}\left(\lambda_{2}\right) & \cdots & L_{N}\left(\lambda_{m}\right)
\end{array}\right)
$$

式(13)で示すように、 $\bar{L}\left(\lambda_{i}\right)$ を波長 $\lambda_{i}$ における $N$ 個の測定データの平 均值とすると、行列 $\mathbf{L}$ の要素の変数間の共分散 $v_{i j}(i, j=1,2, \ldots, m)$ は式(14)で表される。

$$
\begin{aligned}
& \bar{L}\left(\lambda_{i}\right)=\frac{1}{N} \sum_{n=1}^{N} L_{n}\left(\lambda_{i}\right) \\
& v_{i j}=\frac{1}{N-1} \sum_{n=1}^{N}\left[L_{n}\left(\lambda_{i}\right)-\bar{L}\left(\lambda_{i}\right)\right]\left[L_{n}\left(\lambda_{j}\right)-\bar{L}\left(\lambda_{j}\right)\right]
\end{aligned}
$$

$v_{i j}$ を $(i, j)$ 要素とする行列 $\mathbf{V}$ は、共分散行列と呼ばれる $m$ 行 $m$ 列対称 行列である。式(15)より、 $m$ 個の固有值 $\mu_{k}(k=1,2, \ldots, m)$ とそれに 対応する固有ベクトル $\mathbf{A}_{k}$ を求める。

$\mathbf{V} \mathbf{A}_{k}=\mu_{k} \mathbf{A}_{k}$

$\mu_{1}>\mu_{2}>\ldots>\mu_{m}$ となるように $\mathbf{A}_{k}$ を並べると、元の測定データ $L\left(\lambda_{i}\right)$ は $\mathbf{A}_{k}$ を用いて式(16)のように表される。

$$
L\left(\lambda_{i}\right)=\bar{L}\left(\lambda_{i}\right)+\sum_{k=1}^{m} M_{k} A_{k}\left(\lambda_{i}\right)
$$

ここで、 $\mathrm{A}_{k}\left(\lambda_{i}\right)$ はべクトル $\mathbf{A}_{k}$ の $i$ 番目の要素を表す。また、 $\mathbf{A}_{k}$ のス カラー係数 $M_{k}$ は $\mathbf{A}_{k}$ とともに求まる。

式(16)における第 $k$ 次の寄与の大きさは式(17)で定義される寄与 率 $P_{k}$ および式(18)で表される第 $l$ 次までの寄与率の和、すなわち累 積寄与率 $C_{l}$ で評価される。

$$
\begin{aligned}
& P_{k}=\mu_{k} / \sum_{i=1}^{m} \mu_{i} \\
& C_{l}=\sum_{k=1}^{l} P_{k}
\end{aligned}
$$

累積寄与率 $C_{l}$ が十分 1 に近いとき、 $\mathbf{L}$ は $l$ 番目の主成分までで充分 近似されたとし、それより高次の項は無視する。このとき、 $L\left(\lambda_{i}\right)$ は 式(19)のように表せる。 


$$
L\left(\lambda_{i}\right) \cong \bar{L}\left(\lambda_{i}\right)+\sum_{k=1}^{l} M_{k} A_{k}\left(\lambda_{i}\right)
$$

Judd らの手法 17)では、相対分光分布に対して主成分分析を行い、 $\mathrm{xy}$ 色度からスカラー係数 $M_{1}, M_{2}$ を求めて固有ベクトル $\mathbf{A}_{1}, \mathbf{A}_{2}$ から相 対分光分布を合成した。本研究では XYZ 三刺激值の絶対值が得ら れるので、 $M_{1}, M_{2}, M_{3}$ を求めて $\mathbf{A}_{1}, \mathbf{A}_{2}, \mathbf{A}_{3}$ から分光放射輝度を合成す る。ある光のスペクトル $\Phi\left(\lambda_{i}\right)$ の XYZ 三刺激值は式(20)で定義され る。

$$
\left\{\begin{array}{l}
X=\mathrm{K} \sum_{i=1}^{m} \Phi\left(\lambda_{i}\right) \bar{x}\left(\lambda_{i}\right) \Delta \lambda \\
Y=\mathrm{K} \sum_{i=1}^{m} \Phi\left(\lambda_{i}\right) \bar{y}\left(\lambda_{i}\right) \Delta \lambda \\
Z=\mathrm{K} \sum_{i=1}^{m} \Phi\left(\lambda_{i}\right) \bar{z}\left(\lambda_{i}\right) \Delta \lambda
\end{array}\right.
$$

ここで $\mathrm{K}=6831 \mathrm{~m} / \mathrm{W}$ は最大視感度、 $\bar{x}\left(\lambda_{i}\right), \bar{y}\left(\lambda_{i}\right), \bar{z}\left(\lambda_{i}\right)$ は $2^{\circ}$ 視野の等色 関数、 $\Delta \lambda[\mathrm{nm}]$ は測定データの波長間隔、 $m=(780-380) / \Delta \lambda$ である。 式(21), 式(22)で示すように $(\bar{X}, \bar{Y}, \bar{Z}) 、\left(X_{k}, Y_{k}, Z_{k}\right)$ を定めると、式 (19)より $L\left(\lambda_{i}\right)$ の刺激值 XYZ は式(23)のようになる。

$$
\begin{aligned}
& \left(\begin{array}{l}
\bar{X} \\
\bar{Y} \\
\bar{Z}
\end{array}\right)=\mathrm{K} \sum_{i=1}^{m} \bar{L}\left(\lambda_{i}\right)\left(\begin{array}{l}
\bar{x}\left(\lambda_{i}\right) \\
\bar{y}\left(\lambda_{i}\right) \\
\bar{z}\left(\lambda_{i}\right)
\end{array}\right) \Delta \lambda \\
& \left(\begin{array}{c}
X_{k} \\
Y_{k} \\
Z_{k}
\end{array}\right)=\mathrm{K} \sum_{i=1}^{m} A_{k}\left(\lambda_{i}\right)\left(\begin{array}{l}
\bar{x}\left(\lambda_{i}\right) \\
\bar{y}\left(\lambda_{i}\right) \\
\bar{z}\left(\lambda_{i}\right)
\end{array}\right) \Delta \lambda \quad(k=1,2,3) \\
& \left(\begin{array}{c}
X \\
Y \\
Z
\end{array}\right)=\mathrm{K} \sum_{i=1}^{m} L\left(\lambda_{i}\right)\left(\begin{array}{l}
\bar{x}\left(\lambda_{i}\right) \\
\bar{y}\left(\lambda_{i}\right) \\
\bar{z}\left(\lambda_{i}\right)
\end{array}\right) \Delta \lambda=\left(\begin{array}{c}
\bar{X} \\
\bar{Y} \\
\bar{Z}
\end{array}\right)+\sum_{k=1}^{3} M_{k}\left(\begin{array}{c}
X_{k} \\
Y_{k} \\
Z_{k}
\end{array}\right)
\end{aligned}
$$

式(23)を $M_{1}, M_{2}, M_{3}$ について解き、式(24)を得る。 $M_{1}, M_{2}, M_{3}$ は $X, Y$, $Z$ により一意的に決まる。ただし、 $X^{\prime}, Y^{\prime}, Z^{\prime}$ は式(25) とする。

$$
\begin{aligned}
& \left\{\begin{array}{l}
M_{1}=\frac{X^{\prime} Y_{2} Z_{3}+X_{2} Y_{3} Z^{\prime}+X_{3} Y^{\prime} Z_{2}-X^{\prime} Y_{3} Z_{2}-X_{2} Y^{\prime} Z_{3}-X_{3} Y_{2} Z^{\prime}}{X_{1} Z_{3}+X_{2} Y_{3} Z_{1}+X_{3} Y_{1} Z_{2}-X_{1} Y_{3} Z_{2}-X_{2} Y_{1} Z_{3}-X_{3} Y_{2} Z_{1}} \\
M_{2}=\frac{X_{1} Y^{\prime} Z_{3}+X^{\prime} Y_{3} Z_{1}+X_{3} Y_{1} Z^{\prime}-X_{1} Y_{3} Z^{\prime}-X^{\prime} Y_{1} Z_{3}-X_{3} Y^{\prime} Z_{1}}{X_{1} Y_{2} Z_{3}+X_{2} Y_{3} Z_{1}+X_{3} Y_{1} Z_{2}-X_{1} Y_{3} Z_{2}-X_{2} Y_{1} Z_{3}-X_{3} Y_{2} Z_{1}} \\
M_{3}=\frac{X_{1} Y_{2} Z^{\prime}+X_{2} Y^{\prime} Z_{1}+X^{\prime} Y_{1} Z_{2}-X_{1} Y^{\prime} Z_{2}-X_{2} Y_{1} Z^{\prime}-X^{\prime} Y_{2} Z_{1}}{X_{1} Y_{2} Z_{3}+X_{2} Y_{3} Z_{1}+X_{3} Y_{1} Z_{2}-X_{1} Y_{3} Z_{2}-X_{2} Y_{1} Z_{3}-X_{3} Y_{2} Z_{1}}
\end{array}\right. \\
& \left\{\begin{array}{l}
X^{\prime}=X-\bar{X} \\
Y^{\prime}=Y-\bar{Y} \\
Z^{\prime}=Z-\bar{Z}
\end{array}\right.
\end{aligned}
$$

$M_{1}, M_{2}, M_{3}$ と $\mathbf{A}_{1}, \mathbf{A}_{2}, \mathbf{A}_{3}$ とを用いて、式(19)から分光放射輝度 $L\left(\lambda_{i}\right)$ を算出する。

\section{3 主成分分析による固有ベクトルの算出結果}

2.5 で述べたように、全天空画像の撮影と同時に主成分分析を行 う天空の分光放射輝度を分光色彩計（PR-650）で測定した。固有心゙ クトルの算出には 2011 年 12 月 7 日 14:50 15:47 (晴)、2012 年 2 月 9 日 9:48 11:14 (快晴)、同日 14:00 14:37 (量) に測定した合 計 362 組の分光放射輝度データを用いた。図 7 に相関色温度 $1000 \mathrm{~K}$ 毎の度数を示す。これらをもとに共分散行列を用いる主成分分析を 行い、固有ベクトル $\mathbf{A}_{k}$ を算出した。図 8 に $\mathbf{A}_{1}, \mathbf{A}_{2}, \mathbf{A}_{3}$ を示す。なお、 第 2 主成分までの累積寄与率は 0.99 を超えたが、式(24)を用いて $\mathrm{XYZ}$ 三刺激值から $M_{1}, M_{2}, M_{3}$ を一意的に決めるために固有べクトル は $\mathbf{A}_{3}$ まで用いることにする。

\section{4 ビデオ測色法による全天空分光放射輝度分布の測定結果}

3.1 に示した CIE 昼光による方法と 3.2 に示した主成分分析によ る方法により、ビデオ測色法で測定した全天空 XYZ 三刺激值分布 から全天空分光放射輝度分布を算出した。以下、前者をV-CIE、後 者をV-PCA と呼ぶ。また、精度検証のため、2.5 で示したように全 天空画像の撮影と同時に分光色彩計で測定した XYZ 三刺激値から、 3.1 に示した CIE 昼光による方法と 3.2 に示した主成分分析による 方法により分光放射輝度を算出した。以下、前者を S-CIE、後者を S-PCA と呼ぶ。また、分光色彩計で測定した分光放射輝度を真值と 呼ぶ。

分光放射輝度の算出例として、図 9〜図 12 に 2012 年 2 月 9 日の V-CIE、V-PCA、S-CIE、S-PCA、真值を示す。また、これらを表 5 に示す全ての高度・方位角について算出し、それぞれ精度の統計指 標として\%MBE の絶対值 $|\% \mathrm{MBE}| 、 \% \mathrm{RMSE}$ を求めた。その平均 值を表 7 に示寸。なお、CIE 昼光による方法において、CIE 昼光は 相関色温度が約 $25000 \mathrm{~K}$ までの昼光の分光分布を与えるものであり、 それ以上の相関色温度の天空要素には使えないため、相関色温度が $25000 \mathrm{~K}$ を超えた場合、分光放射輝度の算出を行わなかった。さら に、表 8 に S-CIE、S-PCA の高度毎の\%MBE の絶対值 $|\% \mathrm{MBE}|$ お よび\%RMSE の平均值を示す。図 13 に S-CIE、S-PCA について、 相関色温度および\%RMSE 毎の度数を示す。

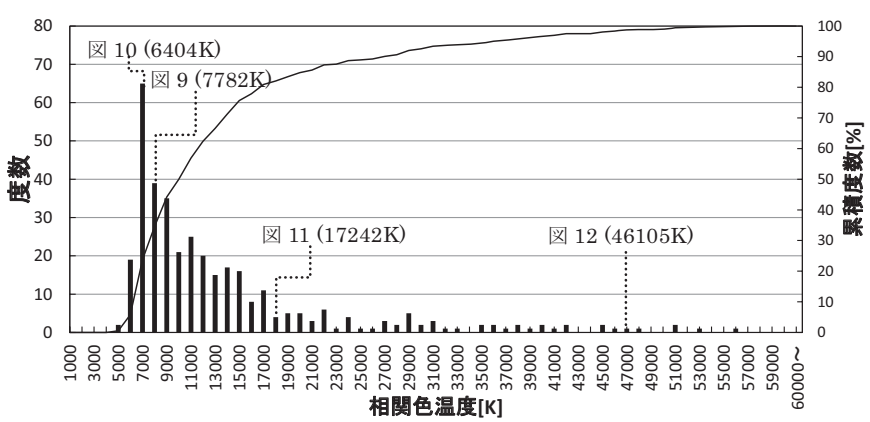

図 7 分光放射輝度データの相関色温度 $1000 \mathrm{~K}$ 毎の度数

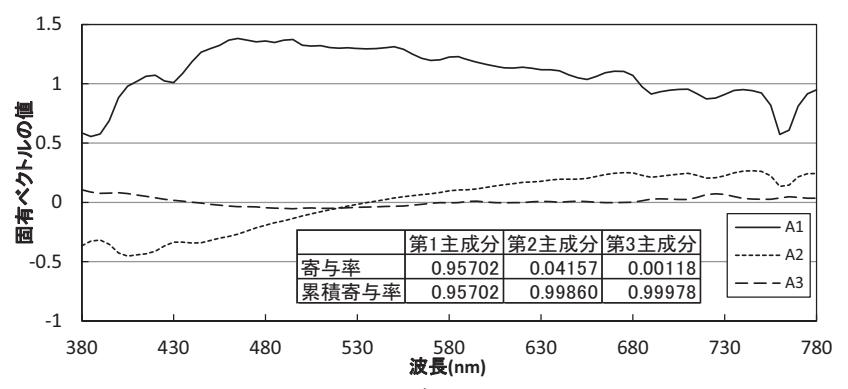

図 8 固有ベクトル

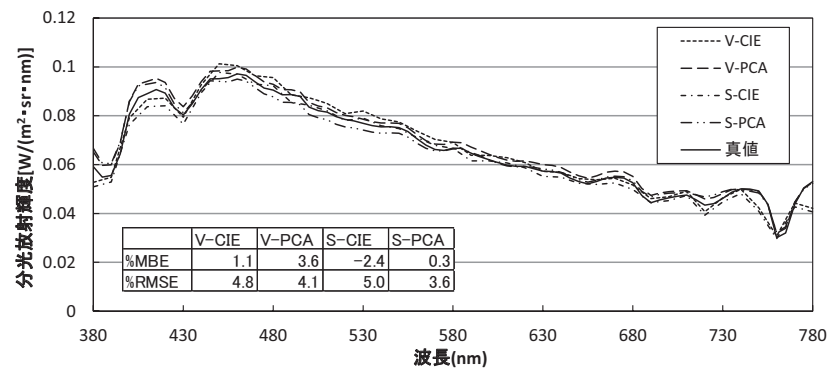

図 9 分光放射輝度の算出值 $\left(14: 31\right.$ 高度 $20^{\circ}$ 方位角 $\left.180^{\circ} 7782 \mathrm{~K}\right)$ 


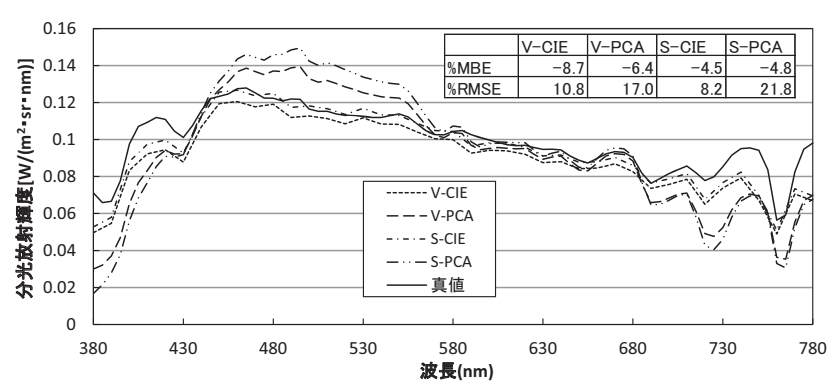

図 10 分光放射輝度の算出值 $\left(11: 04\right.$ 高度 $10^{\circ}$ 方位角 $\left.200^{\circ} 6404 \mathrm{~K}\right)$

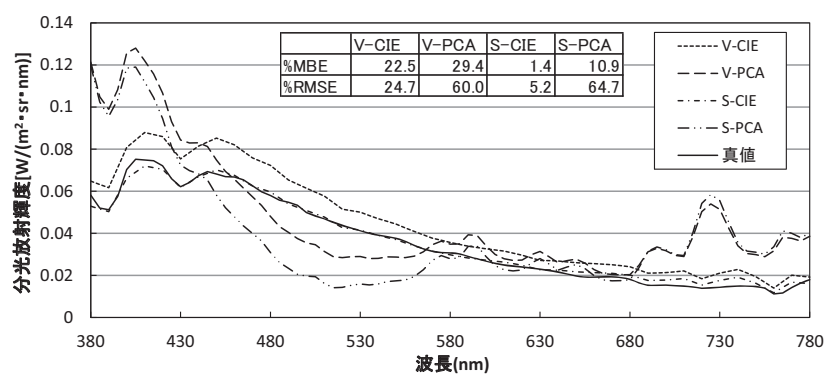

図 11 分光放射輝度の算出值 $\left(14: 03\right.$ 高度 $70^{\circ}$ 方位角 $\left.0^{\circ} 17242 \mathrm{~K}\right)$

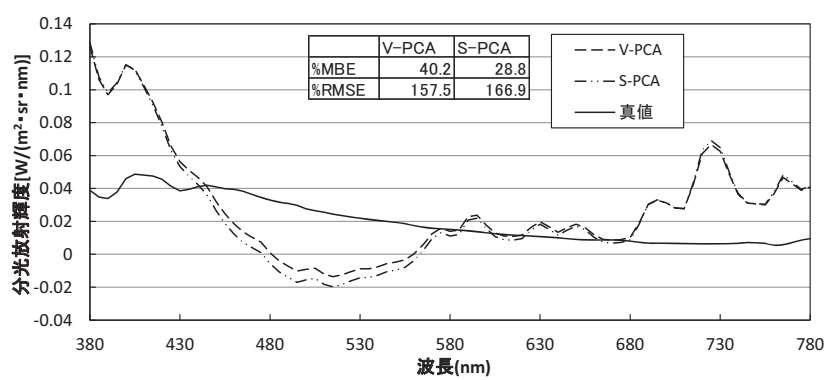

図 12 分光放射輝度の算出值 $\left(10: 01\right.$ 高度 $70^{\circ}$ 方位角 $\left.120^{\circ} 46105 \mathrm{~K}\right)$

表 $7 \% \mathrm{MBE}$ の絶対值、\%RMSE の全天空要素についての平均值

\begin{tabular}{|c|c|c|c|c|c|c|c|c|c|c|}
\hline \multirow{2}{*}{\begin{tabular}{|c|}
$\mathrm{XYZ}$ \\
測定 \\
\end{tabular}} & \multirow{2}{*}{ 算出値 } & \multicolumn{3}{|c|}{ 2月9日 } & \multicolumn{3}{|c|}{ 午前 (快晴) } & \multicolumn{3}{|c|}{ 午後(量) } \\
\hline & & \%MBE & $\%$ RMSE & $n$ & \%MBE & \%RMSE & $\mathrm{n}$ & |\%MBE| & $\%$ RMSE & $\mathrm{n}$ \\
\hline & $\mathrm{V}-\mathrm{CIE}$ & 13.7 & 16.6 & 150 & 17.8 & 20.6 & 63 & 10.8 & 13.7 & 87 \\
\hline & V-PCA & 18.0 & 50.0 & 195 & 22.9 & 70.0 & 105 & 12.1 & 25.8 & 87 \\
\hline & $\mathrm{V}$-CIE & 12.5 & 14.6 & 191 & 13.4 & 15.1 & 78 & 11.9 & 14.2 & 113 \\
\hline & V-PCA & 14.8 & 43.5 & 221 & 17.4 & 58.1 & 108 & 12.4 & 29.5 & 113 \\
\hline 分光色 & S-CIE & 2.3 & 5.2 & 211 & 2.4 & 5.4 & 86 & 2.2 & 5.0 & 125 \\
\hline 彩計 & S-PCA & 7.3 & 43.5 & 230 & 10.4 & 62.3 & 105 & 4.1 & 24.6 & 125 \\
\hline
\end{tabular}

※XYZ 測定欄の SS: $1 / 100$ とSS:1/250 はそれぞれ画像のシャッタースピード

表 8 分光放射輝度の高度毎の $\% \mathrm{MBE}$ の絶対值, $\% \mathrm{RMSE}$ の平均值

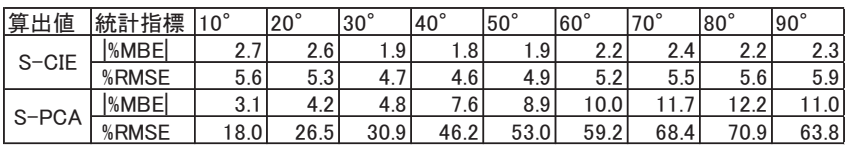

図 9 (7782K)では、V-CIE、V-PCA ともに真值にほぼ一致してお り、\%RMSE は 4〜5\%程度、\%MBE は 1〜4\%程度と小さく、精度 は良好である。図 10 (6404K) は図 9 に比べるとやや劣るものの、 V-CIE、V-PCA の\%RMSE は 10～17\%程度でおおむね良い精度であ る。V-PCA については、図 7 で $6000<\mathrm{CCT} \leqq 7000$ および $7000<$ $\mathrm{CCT} \leqq 8000$ の度数はそれぞれ $65 、 39$ と十分大きく、主成分分析に よってこれらの相関色温度の範囲の分光放射輝度を算出するのに適 した固有ベクトルが得られたと考えられる。

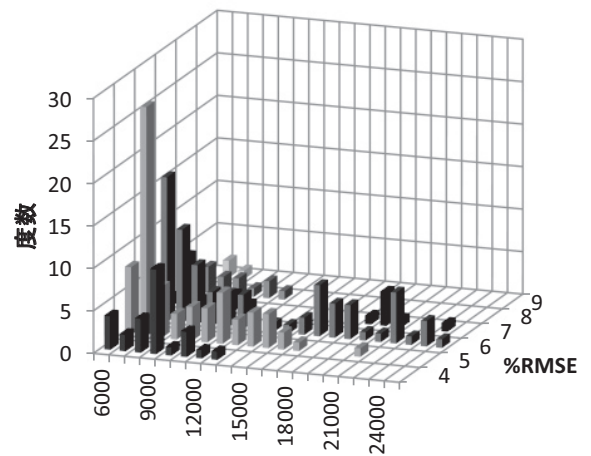

相関色温度(K)

(a) S-CIE

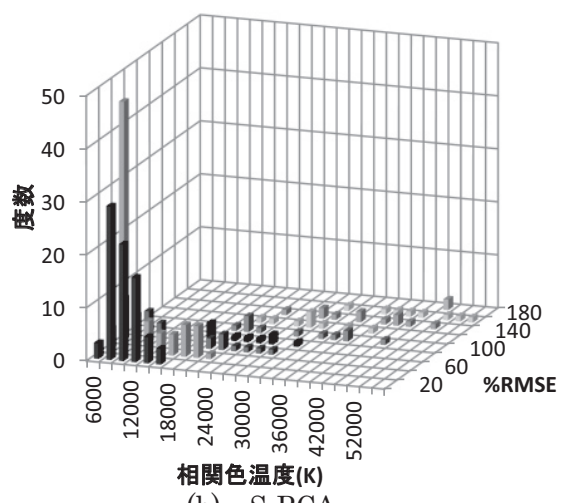

(b) S-PCA

図 13 相関色温度および\%RMSE 毎の度数

一方、図 11 (17242K)では、V-CIE の\%RMSE は $24.7 \%$ と大きい。 これは、S-CIE の\%RMSE が 5.2\%と小さいことから、ビデオ測色 法による XYZ 三刺激值の精度がやや低いためと考えられる。V-PCA の\%RME は $60.0 \%$ と大きく、S-PCA も $64.7 \%$ と大きい。これは、 図 7 で $17000<\mathrm{CCT} \leqq 18000$ の度数は 4 と小さく、主成分分析によ って得られた固有ベクトルがこの相関色温度の範囲の分光放射輝度 を算出するのに適さないものであるためと考えられる。図 12 (46105K)では、相関色温度が $25000 \mathrm{~K}$ を超えているため V-CIE は 算出することができない。V-PCA については、図 7 で $46000<\mathrm{CCT}$ $\leqq 47000$ の度数は 1 であるために、図 11 の V-PCA と同様の理由で 精度が低くなっていると考えられる。以上より、主成分分析による 方法（V-PCA、S-PCA）では、図 7 のヒストグラムでどの相関色温 度の範囲でも十分な度数となるように分光放射輝度の測定データを 追加して主成分分析を行うことで、得られる固有ベクトルの相関色 温度に関する適用範囲が拡大し、分光放射輝度の算出精度が向上す ると考えられる。

表 7 において、CIE 昼光による方法（V-CIE、S-CIE）の精度は 主成分分析による方法（V-PCA、S-PCA）の精度に比べて高い。し かし、CIE 昼光は相関色温度が $25000 \mathrm{~K}$ 以上の天空要素には使えな いため、快晴時はV-PCA、S-PCA より有効データ数が少ない。V-CIE については、快晴時は\%RMSE が 15〜21\%程度、|\%MBE|が 13〜 $18 \%$ 程度、曇天時は $\%$ RMSE が $14 \%$ 程度、| |\%MBE|が 11 \% $12 \%$ 程 度であり、曇天時の方が晴天時より精度がやや高い。これは、S-CIE は快晴時と曇天時ではともに $\% \mathrm{RMSE}$ が $5 \%$ 程度、|\%MBE|が $2 \%$ 程度で精度にほとんど差が無いことから、表 6 で示したようにビデ オ測色值の相関色温度の精度が晴天時に比べて晴天時の方が高いた 
めに分光放射輝度の算出値の精度も晴天時に比べて曇天時の方が高 くなっていると考えられる。V-PCAについては、快晴時は\%RMSE が 58〜 70\%程度、|\%MBE|が 17〜23\%程度、是天時は\%RMSE が $26 \sim 30 \%$ 程度、|\%MBE|が $12 \%$ 程度であり、曇天時の方が晴天時 より精度が高い。これは、S-PCA についても快晴時は\%RMSE が $62.3 \% 、|\% \mathrm{MBE}|$ が $10.4 \%$ 、晴天時は\%RMSE が $24.6 \%$ 、|\%MBE | が $4.1 \%$ で曇天時の方が晴天時より精度が高いことから、主成分分析 による固有ベクトルの相関色温度に関する適用範囲が狭いために相 関色温度の高い青空の分光放射輝度の算出值の精度が低くなってい ると考えられる。

表 8 において、S-PCA は特に高度 $60^{\circ}$ 以上で|\%MBE|が $10 \%$ を 超え\%RMSEも 60〜 70\%程度と大きいが、S-CIE は|\%MBE|が 1.8 ～2.7\%、\%RMSE が 4.6〜 5.9\%とどの高度で平均しても小さく、CIE 昼光による方法は十分な精度があると言える。

図 13 において、S-CIE は相関色温度によらず\%RMSE が 9\%未満 であるが、S-PCA は相関色温度が $24000 \mathrm{~K}$ 以上になると\%RMSE も 40\%以上と大きい。

以上より、CIE 昼光による方法は相関色温度 $25000 \mathrm{~K}$ 以上には使 えないものの、精度は良好であると言える。主成分分析による方法 は、CIE 昼光による方法に比べると精度は低いが、主成分分析を行 う測定データを追加して固有ベクトルの相関色温度に関する適用範 囲が拡大すれば、精度が向上する可能性が高い。

\section{4. おわりに}

本研究では、魚眼レンズ付デジタルカメラによる全天空分光放射 輝度分布の測定法を考案した。その方法は、色彩較正した魚眼レン ズ付デジタルカメラを用いて全天空 XYZ 三刺激值分布を測定し、 CIE 昼光による方法あるいは主成分分析による方法で全天空 XYZ 三刺激值分布から全天空分光放射輝度分布を導出するというもので ある。さらに、実際に魚眼レンズ付デジタルカメラを色彩較正し、 冬季の実測を行ったところ、以下のような結果を得た。

1）汎用のデジタルカメラと魚眼レンズの色彩較正を行い、デジタ ルカメラのビデオ信号值から XYZ 三刺激值の絶対值を求める 色彩較正関数が得られた。

2）色彩較正した魚眼レンズ付デジタルカメラにより、全天空 XYZ 三刺激值分布の絶対值を測定した。その精度はおおむね良好で あった。有彩色の色票を用いて色彩較正を行えば、相関色温度 の範囲が拡大し、相関色温度の高い領域での精度が向上する可 能性がある。

3） 全天空 XYZ 三刺激值分布から、CIE 昼光による方法と、主成 分分析による方法で全天空分光放射輝度分布を導出した。前者 は相関色温度が $25000 \mathrm{~K} よ り$ 高い天空には使えないものの、十 分な精度であった。後者は精度が比較的低かったが、相関色温 度の低い天空は相関色温度の高い天空より精度が高かった。こ れは、主成分分析に入力する分光放射輝度測定データのうち、 相関色温度が高いデータが少なかったためと考えられる。今後、 追加の測定を行い、どの相関色温度の範囲でも十分な度数とな るように測定データを充実させることで精度が向上する可能 性が高い。
注 1）魚眼レンズ付デジタルカメラによる全天空輝度分布の測定に関する既 往の研究 ${ }^{20}$ に拈いて、直射日光の遮蔽の有無による天空輝度の值の変 化はほとんど見られなかったとの結果から、本研究では全天空画像の 撮影に際して直射日光の遮蔽は行わなかった。

\section{参考文献}

1）日本工業規格, 屋内作業場の照明基準, JIS Z 9125, 2007

2) Brainard, G.C., et al.: Action Spectrum for Melatonin Regulation in Humans: Evidence for a Novel Circadian Photoreceptor, The Journal of Neuroscience, Vol.21, No.16, pp.6405-6412, 2001.8

3） 戸田 直宏：サーカディアンリズムへの光の影響，照明学会誌 第 91 巻, 第 10 号, pp.655-658, 2007

4) CIE 15: 2004 Colorimetry, 3rd Edition, 2004

5) Wuttke, S., et al.: Spectral radiance and sky luminance in Antarctica: a case study, Theoretical and Applied Climatology Vol.85, pp.131-148, doi:10.1007/s00704-005-0188-2, 2006

6) 稲垣 卓造, 沖 允人, 中村 洋：日本における天空光の色温度とその分 布に関する研究，日本色彩学会誌 第 13 巻,第 2 号, pp.133-135, 1989.10

7）稲垣 卓造, 沖 允人, 中村 洋: 天空の色温度分布に関する研究・その 2, 日本色彩学会誌，第 14 巻，第 1 号, pp.41-42, 1990.5

8) Chain, C., et al.: A Comprehensive Model of Luminance, Correlated Colour Temperature and Spectral Distribution of Skylight: Comparison with Experimental Data, Solar Energy, Vol. 65, No. 5, pp.285-295, 1999

9) G.G. Roy, et al. : Sky luminance: Standard digital form for modelling, Lighting Research and Technology Vol.27, No.3, pp.161-167, 1995

10）上谷 芳昭，ほか 3 名：全天空輝度分布に応答する昼光照明制御システ ムに関する研究：その 1 昼光照明制御法の開発，日本建築学会近畿支 部研究報告集 環境系，第 46 号, pp.93-96, 2006.6

11) Rossini, E. G., et al.: Maps of sky relative radiance and luminance distributions acquired with a monochromatic CCD camera, Solar Energy, Vol.81, pp.1323-1332, 2007

12) Voss, K. J., et al.: Radiometric and Geometric Calibration of a Visible Spectral Electro-Optic "Fisheye" Camera Radiance Distribution System, Journal of Atmospheric and Oceanic Technology Vol.6, pp.652-662, 1989

13) López-Álvarez, M. A., et al.: Using a trichromatic CCD camera for spectral skylight estimation, Applied Optics Vol.47, No.34, pp.H31-H38, 2008.12

14) Roman, R. et al.: Calibration of an all-sky camera for obtaining sky radiance at three wavelengths, Atmos. Meas. Tech. Discuss., Vol.5, pp.2123-2024, 2012

15）上谷 芳昭: Measurement of CIE Tristimulus Values XYZ by Color Video Images-Development of Video Colorimetry-, 日本建築学会計 画系論文集 第 543 号, pp.25-31, 2001.5

16) ADOBE: AdobeRGB (1998) Color Image Encoding Version 2005-05, May 2005

17) Judd, D. B. et al. : Spectral Distribution of Typical Daylight as a Function of Correlated Color Temperature, Journal of the Optical Society of America, Vol. 54, No. 8, pp.1031-1040, 1964

18）八塚 秀樹，上谷 芳昭：魚眼レンズ付デジタルカメラによる全天空分 光放射輝度分布の測定法に関する研究, 日本建築学会近畿支部研究報 告集，第 52 号 環境系, pp.37-40, 2012.6

19）上谷 芳昭，八塚 秀樹：魚眼レンズ付デジタルカメラによる全天空分 光放射輝度分布の測定法の研究（その 1 ）；（その 2)，日本建築学会 大会学術講演梗概集 環境工学 I, pp.503-504; 505-506, 2012.9

20）西尾信寛，ほか 3 名：ビデオ測色法による天空輝度分布測定法の開発 とその評価, 日本建築学会大会学術講演梗概集 環境工学 I, pp.281-282, 2005.9

（2012年12月 10 日原稿受理， 2013 年 5 月 7 日採用決定） 